\title{
Linguistic analysis of a humorous dialogic discourse (on the material of German-, English - and Russian everyday joke)
}

\author{
Lydmila Tyukina $^{1 *}$, Vladimir Babayan ${ }^{2}$, and Milica Lazović $^{3}$ \\ ${ }^{1}$ Foreign Languages Department, Yaroslavl State Technical University, Yaroslavl, Russian Federation \\ ${ }^{2}$ Foreign Languages Department, Yaroslavl Higher Military Institute of the Air Defense, Yaroslavl, \\ Russian Federation \\ ${ }^{3}$ Institut für Interkulturelle Kommunikation, Stiftung Universität Hildesheim, Hildesheim, Germany
}

\begin{abstract}
The research shows what features and functions distinguish everyday joke from other types of text. It focuses on the genre of joke and its repetitive, dynamic elements in a descriptive context. The leading research question in this paper is: how can general, typical characteristics be used to analyze the joke text in three languages - German, English and Russian? The research is based on the extensive body of texts from the everyday joke, which is a humorous dialogue discourse. The authors of this study have tried to find new approaches to the analysis of everyday jokes. The research aim is not only to find the right way to define and analyze the joke, but also to introduce various approaches, methods and factors that may be relevant to the linguistic description of this type of text, and to compare the texts of the joke in the three above-mentioned languages. In accordance with the specific tasks, the work uses a comprehensive research methodology based on the application of various research methods: comparative analysis of texts in different languages, definition analysis, contextual analysis of lexical unit values, interpretive semantic analysis of contexts in which linguistically specific words and phrases are used, classification and systematizing techniques. More than 450 jokes in the form of dialogues were selected for the analysis method of continuous sampling of language material.
\end{abstract}

\section{Introduction}

The joke is deeply rooted in the social and cultural memory of mankind and covers countless spheres of life, public and private, religious and political, human weaknesses and differences, etc. Joke belongs to the genre of humorous discourse and the material of this study based on joke as a dialogical humorous discourse. The purpose of the article is a linguistic description of the German-, English - and Russian-language joke as a humorous dialogical discourse.

Thus, the main research questions of this work are: defining joke as a separate specific type of discourse, identifying universal and specific characteristics of joke of various

* Corresponding author: 1tyukina@yandex.ru 
(German, English and Russian) linguistic cultures, describing joke as a type of discourse. To solve the questions above, the authors divide the work into theoretical and practical parts. In the last is presented and analyzed the body of more than 450 jokes from German, English, and Russian linguistic cultures that are presented in dialogical form.

\section{Problem Statement and Research Methods}

In accordance with specific tasks, the paper uses a comprehensive research methodology based on the use of various research methods: descriptive method, comparative analysis of texts in different languages, definition analysis, contextual analysis of the meanings of lexical units, interpretative semantic analysis of contexts in which language-specific words and phrases are used, semantic and lexicographic analysis, linguoculturological methods, classification and systematization techniques, the method of continuous sampling of language material.

In this work, the authors consider the concept of "Dialogic discourse" as a coherent text, which is a product of a bilateral verbal act of communication (communication, dialogue), while "its constituent replicas-utterances are produced taking into account the extra linguistic factor of the presence of the addressant and the addressee with their different communicative roles" [1]. The traditional theoretical base of humorous discourse is formed by famous Russian linguists E. Y. Shmeleva and A. D. Shmelev, V. V. Chimik, V. I. Karasik, V. D. Devkin, N. D. Milovskaya, and others. One of the well-known representatives of the study of German-language humorous discourse is Helga Kotthoff, who is engaged, among other things, in the research of conversational humor and the study of gender characteristics of humor [2].

The question of whether a joke belongs to any genre has been discussed for many years. This is due to the fact that joke as a subject of research has acquired the characteristic features of two genres: literary and folk. On the one hand, this can be explained by the origin of the joke, on the other - by differences in oral and written literature as a result of "contamination" of various characteristics of the species - the form of existence and the topic of jokes. That is the joke of the genre characterized by a certain duality. According to E. Ya. Kurganov, "ignoring the duality of a joke... not only makes it difficult, but makes it impossible to fully analyze this unique genre" [3]. Linguist V. V. Chimik considers joke as a unique phenomenon of Russian speech culture [4].

Having chosen an anecdote as the subject of research of its discursive-textual characteristics, we consider it expedient to give definitions of the concepts "humorous discourse" and "joke" in modern linguistics, to study joke as a genre of humorous dialogical discourse, to identify the actual linguistic and extra linguistic features of joke as a genre of humorous dialogical discourse, and to draw a conclusion about the difference between the type of discourse under study and others, with further consideration of the most significant aspects identified when analyzing the joke.

According to V. I. Karasik, a humorous discourse "is a text immersed in a situation of laughing communication". According to the scientist, the following features are characteristic of this situation:

1) the participants communicative intention to avoid a serious conversation,

2) the humorous tone of communication, i.e. the desire to reduce the distance and critically rethink modern concepts in a soft form,

3 ) the presence of certain behaviors in a joking dialogue, accepted in this language culture [5].

If you look at the definition of the Russian term "joke" (from the Greek anekdotos unpublished) in the "Modern encyclopedia - 2000": joke is 
1) a short story about a historical person, an incident;

2) a genre of urban folklore, a topical comic story-a miniature with an unexpected ending, a kind of humorous, often frivolous parable - it becomes clear that the definition of the term "joke" is formed taking into account both characteristics [6].

In German and English, unlike Russian, the literary and folk genre features of a joke are clearly separated. Thus, the concepts joke (in English) and Anekdote (in German) denote a literary joke, a historical joke, while the concepts Witz (in German) and joke (in English) characterize a folk joke. Comparing the characteristic features of these concepts, it becomes obvious that the term der Witz is more suitable for the term "household joke", proposed by N. D. Milovskaya [7].

The study of ethnic stereotypes is necessary to separate the linguistic dimension from all other. This approach to the study of the problem is justified by the fact that the problem of objectivity, reflecting the stereotype of the real features and properties of the national mentality and behavioral models of an ethnic group, is not included in the field of linguistics. The scientist believes that, first of all, the linguistic perspective of the problem is to determine the spheres of life of this ethnic community, the personal traits and properties of the people it consists of, their intellectual, psychological and anthropological features, which then become the subject of evaluation. In addition, the process of studying national stereotypes includes the analysis of language units that can be interpreted as a means of explaining ethnic stereotypes. These linguistic units include phraseological units, syntactic constructions, attribute combinations, comparative sentences, Proverbs, sayings, anecdotes that indicate explicitly or implicitly certain properties of representatives of the corresponding nationality. In addition to the fact that ethnic and cultural stereotypes serve as a means of reflecting the national character, they also have another characteristic - the spread of ethnic humor.

\section{Research Questions}

Despite the fact that the authors chose jokes in the form of a dialogue, certain difficulties arise during studying and comparing examples of the same type of joke text. In order to conclude that jokes are structurally related, which also explains their identical function, the first step would be to determine their structural similarity. B. Marfurt considers structural similarity as a problem of preliminary understanding, which characterizes access to the object of research and like the choice of examples, affects the interpretation of results [8]. From the point of view of the text, a joke is a unity of two (sometimes three) basic structural and compositional components (thematic series): the introduction, the main part and the conclusion (witticism, Pointe).

Thus, the body of jokes in this work faces unintended subjective analysis. From myriad jokes, 450 jokes in the form of dialogues in Russian, English and German languages were selected using a continuous sampling method to describe their organizational structure and identify their function. In order to compare the results of the study, joke texts of the same structure are analyzed. In earlier works, the authors have already analyzed jokes from the point of view of introduction. The study revealed that jokes from all three linguistic cultures often have a relatively large introduction and background (this is typical for more than 50\% of German - and English-language jokes and 20\% of Russian-language jokes). Almost a third of all jokes are accompanied by a short introduction (here are jokes in Russian, English and German in the range from 30 to $45 \%$, that are quite close to each other). A large number of Russian language jokes (more than 30\%) do not have any introduction at all, while there are only $6 \%$ of German-language jokes without introduction, and $10 \%$ of English-language ones. It is worth noting that among English jokes has not been found any 
without the verb-predicate in introductive replica. That can explain the grammatical structure of English in contrast to German and Russian languages, where the attitude to the word can be showed by the article (in German) or by the case ending (in Russian). The structure of English sentence always contains a verb [9].

\section{Purpose of the Study}

Further, the research of joke texts included the selection of identical jokes in all three languages. However, there were not many such jokes, but the authors tried to conduct a small linguistic research of them. This article analyzes three jokes in Russian, German, and English languages that have the same content.

(1) (de) Ein Mann geht in eine Bar und setzt sich an die Theke.

Fragt der Kellner: "Warum denn so traurig?"

Sagt der Mann: "Meine Frau hat gesagt, sie will einen Monat lang nicht mit mir reden!"

Sagt der Kellner: "Das ist doch nicht so schlimm. Diese Zeit geht auch vorbei."

Antwortet der Mann: "Ja, heute!" [10]

(2) (eng) A man walked into a bar, looking sad, and the bartender asked him,

"What's the matter?"

"My wife and I had a fight, and she told me that she wasn't going to speak to me for a month. And the month is up today" [11].

(3) (rus) В баре грустный мужик заказывает рюмку за рюмкой. В конце концов бармен не выдерживает и спрашивает:

— Что случилось-то?

- Да, блин. С женой поругался. Она обещала месяц со мной не разговаривать.

- Да уж... Представляю, как тебе хреново.

- И не говори! Сегодня последний день... [12].

After analyzing the structure of the text we get the following breakdown of the joke into its component parts:

Introduction, that is presented by the following story-telling: (de) Ein Mann geht in eine Bar und setzt sich an die Theke. Fragt der Kellner / (eng) A man walked into a bar, looking sad, and the bartender asked him, / (rus) В баре грустный мужик заказывает рюмку за рюмкой. В конце концов бармен не выдерживает и спрашивает...

The main part (dramatization of the text): (de) Sagt der Mann: "Meine Frau hat gesagt, sie will einen Monat lang nicht mit mir reden!". Sagt der Kellner: "Das ist doch nicht so schlimm. Diese Zeit geht auch vorbei." / (eng) "My wife and I had a fight, and she told me that she wasn't going to speak to me for a month. / (rus) - Что случилось-то? - Да, блин. С женой поругался. Она обещала месяц со мной не разговаривать. - Да уж... Представляю, как тебе хреново.

Pointe (conclusion): (de) Antwortet der Mann: "Ja, heute!" / (eng) And the month is up today. / (rus) - И не говори! Сегодня последний день...

We consider it appropriate to review the problem of occurrence of a joke from a linguistic point of view. The explanatory sentence (or declarative phrase) is a rather long introduction, followed by the dialogue itself, consisting of questions and answers. Joke ends with a pointe that contains a direct speech from one of the participants of the dialogue. From the point of view of story-telling strategy, two grammatical tenses are used - present and past, while in the Russian and German versions the introduction is given in the present tense, and in the English text - in the past. If we review the situation of a joke, it is a fairly common type of joke from the series "in the bar" or "Husband and wife". The location of the joke - pub, event - husband's grief because his wife is silent since the last argument. In 
the dialogue participate the bartender and the visitor of the bar, who are producers of the analyzed bilateral speech exchange. We can assume that the visiting time is the evening.

The text of the joke is embellished with additional information that is given in the introduction: the man who went to the bar is sad. Where does the discrepancy between the situation and the anecdotal nature of the story come from? The whole absurdity of what is happening lies in the last sentence of the visitor of the bar. Up to the last sentence, the listener does not understand that what he is experiencing is not that he quarreled with his wife. He is sad because today is the last day when his wife does not talk to him. Tomorrow will start a regular routine life and he will have to deal with his wife. Analyzing the discrepancy between the Pointe of the main part, we come to the conclusion that this is a dynamically presented type of dialogue. In addition, as we see, the husband does not finish his remark, as a result of which the resolution of the question is incomplete and a humorous effect occurs in the analyzed dialogue.

\section{Conclusion}

If we consider the joke from the point of view of discourse, we can say that the joke is an epic small form and is usually designed in the form of prose. It contains an event from the life of a famous person. Joke is most often transmitted orally, is diverse and, thus, changeable. However, jokes are often found in written form and, therefore, may also be available in text form. As a rule, it is impossible to determine the actual author of the joke. Jokes are not necessarily authentic and therefore do not always correspond to the facts. However, they are usually referred to as appropriate if they properly reflect the distinctive feature of the person or situation.

Note that the Dialogic environment is the most natural space of existence of the joke, as it is in the dialogue than the author (which is almost always unknown in any form of folk art) and the recipient-the listener, there is also a distributor, who is also the executor of the anecdote, which communication set out as quickly as possible to pass on the joke to another person, to share the humorous voice work. In combination with verbal variations of the main text, the joke is usually used as an oral "live" speech.

Thus, based on all of the above, it is possible to convincingly qualify an anecdote as a special genre of humorous dialogical (monologue) discourse, which is a coherent humorous (comic) text immersed in a specific communicative (speech) situation. The state that pushes the recipients (recipients/ listeners) of such a discourse - joke - to the creative process of its understanding, perception, interpretation and reflection is very characteristic of this genre of discourse. The process of "thinking through" especially clearly conveys the essence of a modern joke. Often, to understand a particular joke, it is not enough for the recipient (recipient/ listener/ reader) to hear or read the joke, they also need to have some basic information (background knowledge) or be an expert in some areas of human activity.

\section{Acknowledgments}

This paper was financially supported by the Russian Foundation for Basic Research, grant No. 20-012-22046. 


\section{References}

1. V.N. Babayan, L.A. Tyukina, On The issue of the unit of dialogical discourse // Linguodidactics in a non-linguistic University: traditional and innovative approaches: collection of scientific articles based on the materials of the II International scientific and practical conference, Yaroslavl, May 14-16, 2020, [Electronic resource], pp. 20 - 21 (YSTU publishing house, Yaroslavl, 2020)

2. H. Kotthoff, Linguistik und Humor // Komik. Ein interdisziplinäres Handbuch / Hrsg. von U. Wirth. Stuttgart: Metzler, S. 112-122 (2017)

3. E. Kurganov, Anecdote as a genre (Academic Project, Moscow, 1997)

4. V.V. Chimik, Anekdot as a unique phenomenon of Russian speech culture // Anekdot as a phenomenon of culture: materials of the round table (November 16, 2002), pp. 17-31 (Saint Petersburg philosophical society, Saint Petersburg, 2002)

5. V.I. Karasik, Language circle: personality, concepts, discourse (Change, Volgograd, 2002)

6. Modern encyclopedia. URL: https://rus-modern-enc.slovaronline.com/775-A2

7. N.D. Milovskaya, German language household anecdote as a specific type of humorous discourse: Diss. ... d. Philol. n., Ivanovo (2011)

8. M. Bernhard / Brekl, Herbert E. [u.a.] (Hrsg.): Textsorte Witz. Möglichkeiten einer sprachwissenschaftlichen Textsorten-Bestimmung. Tübingen: Niemeyer (Linguistische Arbeiten. 52), pp. 37-38 (1977)

9. L.A. Tyukina, V.N. Babayan, Structural and compositional analysis of everyday jokes in German, English and Russian as an object of humorous dialogical discourse in Philological Sciences. Questions of theory and practice, Volume 13, Issue 9, pp 286 - 292, Tambov (2020)

10. Witze.net. URL: http://witze.net/bar-witze.

11. Angelo.edu URL: https://www.angelo.edu/faculty/kboudrea/cheap/cheap3 bars.htm.

12. Vse-shutochki.ru. URL: https://vse-shutochki.ru/anekdot/6506 